\title{
Protein phosphatase-type $2 B$ is involved in the regulation of the acrosome reaction but not in the temperature-dependent flagellar movement of fowl spermatozoa
}

\author{
K Ashizawa, G J Wishart ${ }^{1}$, A R A H Ranasinghe, S Katayama and Y Tsuzuki \\ Laboratory of Animal Reproduction, Faculty of Agriculture, University of Miyazaki, Miyazaki 889-2192, \\ Japan and ${ }^{1}$ Department of Molecular and Life Sciences, University of Abertay Dundee, Dundee DD1 1HG, UK
}

Correspondence should be addressed to K Ashizawa; Email: ashizawa@cc.miyazaki-u.ac.jp

\begin{abstract}
The motility and acrosomal integrity of fowl spermatozoa in $\mathrm{TES} / \mathrm{NaCl}$ buffer, with or without homogenized inner perivitelline layers (IPVL) prepared from laid fowl eggs, was almost negligible at $40{ }^{\circ} \mathrm{C}$. However, motility became vigorous even at $40{ }^{\circ} \mathrm{C}$ when $2 \mathrm{mmol} \mathrm{CaCl}_{2} / \mathrm{l}$ was added, and the acrosome reaction was also stimulated in the presence, but not in the absence, of IPVL. The presence of deltamethrin or fenvalerate, specific inhibitors of protein phosphatase-type 2B (PP2B), did not permit the restoration of motility at $40^{\circ} \mathrm{C}$ but, in the presence of IPVL, these compounds stimulated the acrosome reaction in a dosedependent manner in the range of $1-1000 \mathrm{nmol} / \mathrm{l}$. These results suggest that IPVL is necessary for the activation of the acrosome reaction in fowl spermatozoa and that $\mathrm{Ca}^{2+}$ plays an important role in the stimulation of motility and acrosomal exocytosis. Furthermore, it appears that the intracellular molecular mechanisms for the regulation of the acrosome reaction of fowl spermatozoa are different from those for the restoration of motility, i.e. protein dephosphorylation by PP2B in the former but not in the latter case.

Reproduction (2004) 128 783-787
\end{abstract}

\section{Introduction}

The acrosome of spermatozoa is a Golgi-derived organelle that forms a cap over the anterior part of the nucleus. The acrosome reaction, which is an exocytotic secretory response, is required for sperm penetration and fusion with the egg plasma membrane (Rotem et al. 1992) and involves the following: fusion of the outer acrosomal membrane with the overlying plasma membrane; vesiculation and disappearance of the fused membranes; and release of enzymes and other components contained within the acrosomal matrix (Oura \& Toshimori 1990).

Like other exocytotic events, the acrosome reaction can be stimulated by a variety of signalling pathways, including a $\mathrm{Ca}^{2+}$-dependent process. In mammalian spermatozoa, several $\mathrm{Ca}^{2+}$-dependent processes have been shown to occur, including activation of phospholipases $\mathrm{C}$ and $\mathrm{A} 2$, protein kinase $\mathrm{C}$ and $\mathrm{CAMP}$-dependent protein kinase pathways. This means that protein phosphorylation seems to play a primary role in the second messenger regulatory mechanisms of the acrosome reaction (for review see Benoff 1998, Breitbart \& Naor 1999, Baldi et al. 2000, Guraya 2000, Topfer-Petersen et al. 2000, Urner \& Sakkas 2003).

If phosphorylation is required for the activation of the acrosome reaction, then dephosphorylation of proteins by specific regulatory phosphatases should also affect the acrosome reaction. Such regulatory serine/threonine protein phosphatases are classified into four main enzymes: type 1 (PP1), type 2A (PP2A), type 2B (PP2B) and type 2C (PP2C) (Cohen 1989). With regard to fowl sperm motility, it has been proposed that inhibition of sperm motility at body temperature $\left(40^{\circ} \mathrm{C}\right)$, known as the reversible temperature-dependent immobilization, may be due to the activation of PP1 (Ashizawa et al. 1994a, 1997). However, limited information is available on the involvement of protein phosphatases in the regulation of acrosome reaction in almost all species from invertebrates to vertebrates. We report here that $\mathrm{PP} 2 \mathrm{~B}$ appears to be involved in the regulation of the acrosome reaction of fowl spermatozoa, but not their flagellar movement at body temperature, since the addition of specific inhibitors of PP2B significantly stimulated the acrosome reaction, but did not activate motility at $40^{\circ} \mathrm{C}$.

\section{Materials and Methods}

\section{Animals and preparation of spermatozoa}

Commercial White Leghorn roosters (Babcock strain; Akagi Poultry Breeding Farm, Miyazaki, Japan) were used 
throughout the study. All birds were housed in individual cages and fed ad libitum on a commercial breeder diet. They were exposed to a photoperiod of $14 \mathrm{~h}$ light:10 h darkness.

Semen was collected by the method of Bogdonoff \& Shaffner (1954). Samples of semen pooled from four to six males were diluted approximately 10 -fold in $150 \mathrm{mmol}$ $\mathrm{NaCl} /$ l with $20 \mathrm{mmol}$ TES ( $\mathrm{N}$-Tris-[hydroxymethyl]-methyl2-aminoethanesulfonic acid)// at $\mathrm{pH} 7.4$ and centrifuged at $700 \mathrm{~g}$ for $13 \mathrm{~min}$ at room temperature $\left(20-25^{\circ} \mathrm{C}\right)$. The washed spermatozoa were reconstituted in the same buffer to give a final concentration of approximately $6 \times 10^{8}$ cells $/ \mathrm{ml}$.

\section{Chemicals}

Deltamethrin and fenvalerate, specific inhibitors of PP2B, were purchased from Calbiochem-Novabiochem Co. (La Jolla, CA, USA). ATP, bovine serum albumin (BSA), desiccated firefly tails, fluorescein isothiocyanate (FITC)-conjugated peanut agglutinin (PNA) and TES were obtained from Sigma Chemical Co. (St Louis, MO, USA). Bicinchoninic acid protein assay reagent was from Pierce Chemical Co. (Rockford, IL, USA). Other chemicals were of reagent grade from Nacalai Tesque, Inc. (Kyoto, Japan).

\section{Analysis of acrosome reaction and motility of spermatozoa}

The homogenized inner perivitelline layers (IPVL) were prepared from laid fowl eggs, using a Teflon-glass homogenizer on ice. The protein concentrations of IPVL were adjusted to $75 \mu \mathrm{g} / \mathrm{ml}$ with TES/NaCl buffer ( $\mathrm{pH} 7.4$ ), using BSA as a standard. With or without IPVL, fowl spermatozoa were incubated for $30 \mathrm{~min}$ at $40^{\circ} \mathrm{C}$. Sperm concentrations were adjusted to $1.2 \times 10^{7}$ cells $/ \mathrm{ml}$. The dose-response of the acrosome reaction and motility was measured in the presence of various concentrations of deltamethrin or fenvalerate and the effects of the addition of $\mathrm{CaCl}_{2}$ were also examined. Acrosome-reacted spermatozoa were identified using a fluorescent microscope and FITC-conjugated PNA which binds to acrosome-reacted, but not acrosome-intact, spermatozoa. The protocols for the preparation of IPVL and the assessment of acrosome reaction were essentially those described by Robertson et al. (1997) and Horrocks et al. (2000) respectively.

The suspension of spermatozoa was placed into a microscope slide chamber (UR-157 type; Sekisui Chemical Co. Ltd, Tokyo, Japan) on a thermostatically controlled warm plate, and the motility of spermatozoa was recorded by videomicroscopy (magnification on a 12-inch black and white monitor was approximately $\times 600$ ) at $40^{\circ} \mathrm{C}$ (Katz \& Overstreet 1981).

The percentages of acrosome reaction and motility were made on a total of approximately 100 spermatozoa distributed uniformly among three or more fields.

\section{Analysis of ATP concentrations of spermatozoa}

ATP content of spermatozoa in the absence of IPVL was assayed by firefly bioluminescence in a boiled extract (Wishart 1982). Numbers of spermatozoa were estimated by the method of Wishart \& Ross (1985), using a doublebeam spectrophotometer (Model UV-150-02; Shimadzu, Kyoto, Japan). The concentration of ATP was expressed in terms of nmol ATP $/ 10^{9}$ spermatozoa.

\section{Statistical analysis}

Percentages of acrosome reaction and motility were transformed using arc sine transformation. All data were subjected to statistical analysis by Duncan's multiple-range tests (Duncan 1955).

\section{Results}

The motility of spermatozoa in TES/ $\mathrm{NaCl}$ buffer (control) with or without IPVL at $40^{\circ} \mathrm{C}$ was almost negligible (Figs 1a-3a). However, motility became vigorous at $40^{\circ} \mathrm{C}$ when $2 \mathrm{mmol} \mathrm{CaCl}_{2} / \mathrm{l}$ was added (Fig. 3a), and the acrosome reaction was stimulated in the presence but not in the absence of IPVL (Fig. 3b). Deltamethrin or fenvalerate, specific inhibitors of PP2B, did not restore motility at $40^{\circ} \mathrm{C}$ (Figs $1 \mathrm{a}$ and $2 \mathrm{a}$ ) but did, in the presence of IPVL, induce the acrosome reaction in a dose-dependent manner in the range of $1-1000 \mathrm{nmol} / \mathrm{l}$ (Figs $1 \mathrm{~b}$ and 2b). Deltamethrin stimulated the acrosome reaction at a 10-fold lower concentration than fenvalerate. This might be due to the different potency of these inhibitors, since deltamethrin is approximately 10- to 100-fold more effective than fenvalerate as an inhibitor of PP2B (Enan \& Matsumura 1992). The presence of both $\mathrm{Ca}^{2+}$ and inhibitor with IPVL resulted in slightly higher stimulation of the acrosome reaction than the addition of $\mathrm{Ca}^{2+}$ or inhibitor alone, but this was not significant (Fig. 3b).

The ATP concentrations of spermatozoa following exposure to deltamethrin or fenvalerate at $40^{\circ} \mathrm{C}$ were almost the same values compared with those of untreated spermatozoa (control). Additionally, the ATP concentrations of spermatozoa decreased significantly in the presence of $\mathrm{Ca}^{2+}$ alone or $\mathrm{Ca}^{2+}$ with inhibitor, presumably due to the restoration of motility (Fig. 4).

\section{Discussion}

At the time of ovulation, the avian oocyte is surrounded by the IPVL (Bain \& Hall 1969), which may be considered to be analogous to the mammalian zona pellucida. In fact, it was recently shown that an IPVL glycoprotein of approximately $34 \mathrm{kDa}$ has a high degree of homology to murine zona pellucida protein-3 (Waclawek et al. 1998), which acts as the primary sperm binding protein (Bleil \& Wassarman 1980) and triggers the acrosome reaction (Bleil \& Wassarman 1983). In addition, extracellular $\mathrm{Ca}^{2+}$ 

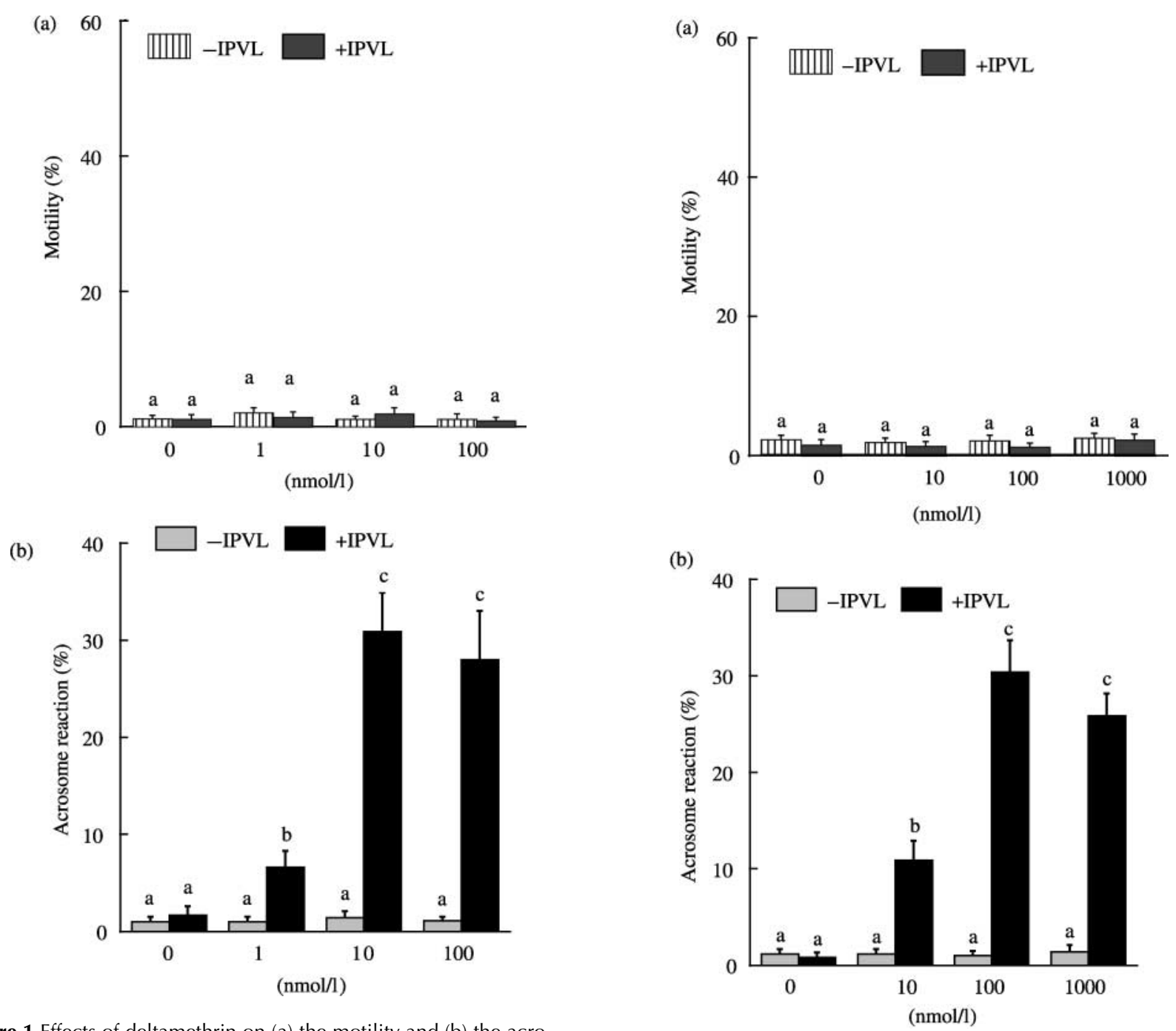

Figure 1 Effects of deltamethrin on (a) the motility and (b) the acrosome reaction of fowl spermatozoa incubated with or without IPVL at $40^{\circ} \mathrm{C}$. Each value represents the mean \pm S.E.M. of five samples of spermatozoa. Values with different superscripts differ significantly $(P<0.05)$ from each other.

is known to be required for the induction of the acrosome reaction in most species (Fraser 1995). The present results confirm that, in fowl spermatozoa, the IPVL is necessary for the activation of the acrosome reaction and that $\mathrm{Ca}^{2+}$ also plays an important role in the stimulation of acrosomal exocytosis (Robertson 1999).

At the avian body temperature of $40^{\circ} \mathrm{C}$, when suspended in a simple medium of buffered $\mathrm{NaCl}$, fowl spermatozoa become immotile (Munro 1938, Ashizawa \& Nishiyama 1978, Ashizawa et al. 1989). Motility is restored by decreasing the temperature or by the addition of $\mathrm{Ca}^{2+}$ or body fluids such as seminal plasma or the fluid of the female ovarian pocket taken at the time of ovulation (Ashizawa \& Wishart 1987, 1992, Wishart \& Ashizawa 1987, Ashizawa et al. 1994b). The present results show that the presence of IPVL has no effect on this phenomenon and that $\mathrm{Ca}^{2+}$, but not PP2B inhibitors, stimulate the

Figure 2 Effects of fenvalerate on (a) the motility and (b) the acrosome reaction of fowl spermatozoa incubated with or without IPVL at $40^{\circ} \mathrm{C}$. Each value represents the mean \pm S.E.M. of five samples of spermatozoa. Values with different superscripts differ significantly $(P<0.05)$ from each other.

motility of spermatozoa at $40^{\circ} \mathrm{C}$. However, both $\mathrm{Ca}^{2+}$ and PP2B inhibitors were able to induce the acrosome reaction in fowl spermatozoa in the presence of IPVL. Therefore, it seems that $\mathrm{Ca}^{2+}$ is necessary for the stimulation of both motility and the acrosome reaction, but that PP2B might be involved in the regulation of the acrosome reaction. During these incubations, spermatozoa maintained almost the same concentrations of intracellular ATP as those of the control (no addition of PP2B inhibitors), in spite of the inhibition of motility. Thus, it appears that the addition of PP2B inhibitors does not simply affect membrane damage or inhibit energy production in these spermatozoa, but may be acting on some part of the regulatory cascade in the acrosome reaction: the inhibitory dephosphorylation action of PP2B might occur in the cascade between sperm-IPVL receptor binding and the 

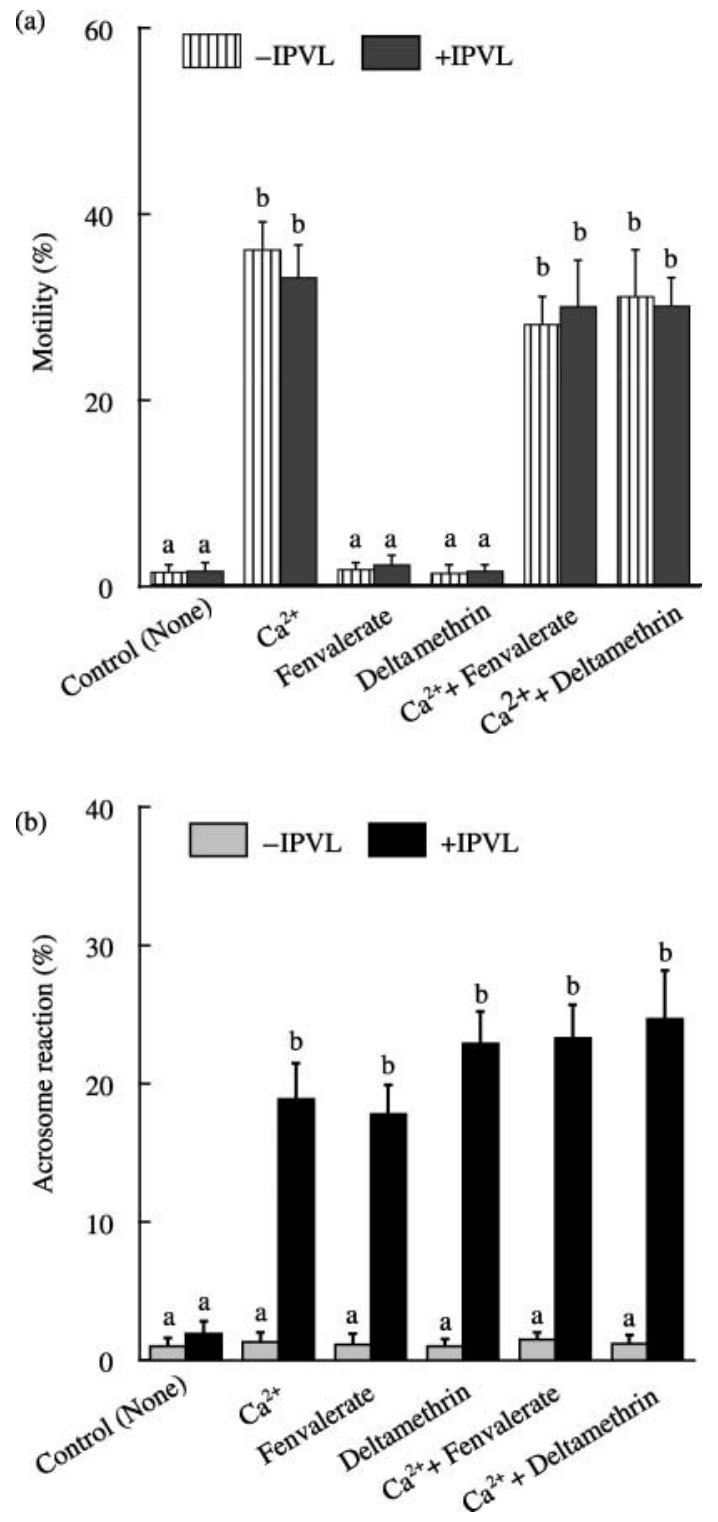

Figure 3 Effects of $\mathrm{Ca}^{2+}(2 \mathrm{mmol} / \mathrm{l})$, fenvalerate $(100 \mathrm{nmol} / \mathrm{l})$ and deltamethrin $(10 \mathrm{nmol} / \mathrm{l})$ on (a) the motility and (b) the acrosome reaction of fowl spermatozoa incubated with or without IPVL at $40^{\circ} \mathrm{C}$. Each value represents the mean \pm S.E.M. of five samples of spermatozoa. Values with different superscripts differ significantly $(P<0.05)$ from each other.

acrosome reaction. However, the precise working point is still unclear.

In conclusion, the intracellular molecular mechanisms for the regulation of the acrosome reaction of fowl spermatozoa are different from those for the temperaturedependent immobilization and restoration of motility, i.e. protein dephosphorylation by PP2B in the former but not in the latter case. We are pursuing investigation of the possible involvement of the other classes of serine/threonine protein phosphatase, such as PP1 and PP2A, in the regulation of acrosome reaction.

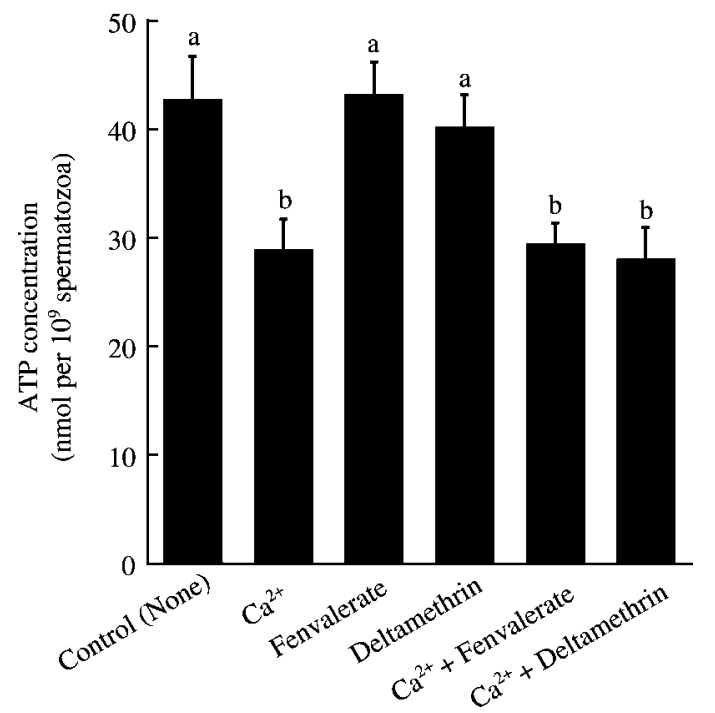

Figure 4 Effects of $\mathrm{Ca}^{2+}(2 \mathrm{mmol} / \mathrm{l})$, fenvalerate $(100 \mathrm{nmol} / \mathrm{l})$ and deltamethrin $(10 \mathrm{nmol} / \mathrm{l})$ on the ATP concentrations of fowl spermatozoa incubated without IPVL at $40^{\circ} \mathrm{C}$. Each value represents the mean \pm S.E.M. of five samples of spermatozoa. Values with different superscripts differ significantly $(P<0.05)$ from each other.

\section{Acknowledgements}

This study was supported by a grant from the Ministry of Education, Science and Culture, Japan (No. 14560236).

\section{References}

Ashizawa K \& Nishiyama H 1978 Effects of temperature on the vigour of motility, oxygen consumption and duration of motility of fowl spermatozoa under aerobic conditions. Japanese Poultry Science 15 264-266.

Ashizawa K \& Wishart GJ 1987 Resolution of the sperm motilitystimulating principle of fowl seminal plasma into $\mathrm{Ca}^{2+}$ and an unidentified low molecular weight factor. Journal of Reproduction and Fertility 81 495-499.

Ashizawa K \& Wishart GJ 1992 Factors from fluid of the ovarian pocket that stimulate sperm motility in domestic hens. Journal of Reproduction and Fertility 95 855-860.

Ashizawa K, Maeda S \& Okauchi K 1989 The mechanisms of reversible immobilization of fowl spermatozoa at body temperature. Journal of Reproduction and Fertility 86 271-276.

Ashizawa K, Wishart GJ, Tomonaga H, Nishinakama K \& Tsuzuki Y 1994a Presence of protein phosphatase type 1 and its involvement in temperature-dependent flagellar movement of fowl spermatozoa. FEBS Letters 350 130-134.

Ashizawa K, Tomonaga H \& Tsuzuki Y 1994b Regulation of flagellar motility of fowl spermatozoa: evidence for the involvement of intracellular free $\mathrm{Ca}^{2+}$ and calmodulin. Journal of Reproduction and Fertility $101265-272$.

Ashizawa K, Hashimoto K \& Tsuzuki Y 1997 Regulation of fowl sperm flagellar motility by protein phosphatase type 1 and its relationship with dephosphorylation of axonemal and/or accessory cytoskeletal proteins. Biochemical and Biophysical Research Communications 235 108-112.

Bain JM \& Hall JM 1969 Observations on the development and structure of the vitelline membrane of the hen's egg: an electron microscope study. Australian Journal of Biological Sciences 22 $653-665$ 
Baldi E, Luconi M, Bonaccorsi L, Muratori M \& Forti G 2000 Intracellular events and signalling pathways involved in sperm acquisition of fertilizing capacity and acrosome reaction. Frontiers in Bioscience 5 e110-e123.

Benoff S 1998 Modelling human sperm-egg interactions in vitro: signal transduction pathways regulating the acrosome reaction. Molecular Human Reproduction 4 453-471.

Bleil JD \& Wassarman PM 1980 Mammalian sperm-egg interaction: identification of a glycoprotein in mouse egg zonae pellucidae possessing receptor activity for sperm. Cell $20873-882$.

Bleil JD \& Wassarman PM 1983 Sperm-egg interactions in the mouse: sequence of events and induction of the acrosome reaction by a zona pellucida glycoprotein. Developmental Biology 95 317-324.

Bogdonoff PD Jr \& Shaffner CS 1954 The effect of $\mathrm{pH}$ on in vitro survival, metabolic activity, and fertilizing capacity of chicken semen. Poultry Science 33 665-669.

Breitbart H \& Naor Z 1999 Protein kinases in mammalian sperm capacitation and the acrosome reaction. Reviews of Reproduction 4 151-159.

Cohen P 1989 The structure and regulation of protein phosphatases. Annual Review of Biochemistry $\mathbf{5 8}$ 453-508.

Duncan DB 1955 Multiple range and multiple $F$ tests. Biometrics 11 $1-42$.

Enan E \& Matsumura F 1992 Specific inhibition of calcineurin by type II synthetic pyrethroid insecticides. Biochemical Pharmacology 43 1777-1784.

Fraser LR 1995 Ionic control of sperm function. Reproduction, Fertility and Development 7 905-925.

Guraya SS 2000 Cellular and molecular biology of capacitation and acrosome reaction in spermatozoa. International Review of Cytology 199 1-64.

Horrocks AJ, Stewart S, Jackson L \& Wishart GJ 2000 Induction of acrosomal exocytosis in chicken spermatozoa by inner perivitelline-derived N-linked glycans. Biochemical and Biophysical Research Communications 278 84-89.

Katz DF \& Overstreet JW 1981 Sperm motility assessment by videomicrography. Fertility and Sterility 35 188-193.
Munro SS 1938 Fowl sperm immobilization by a temperature-media interaction and its biological significance. Quarterly Journal of Experimental Physiology 27 281-287.

Oura C \& Toshimori K 1990 Ultrastructural studies on the fertilization of mammalian gametes. International Review of Cytology 122 105-151.

Robertson L 1999 Sperm-Egg Interaction in Birds: Assays and Mechanisms, PhD Thesis. University of Abertay Dundee.

Robertson L, Brown HL, Staines HJ \& Wishart GJ 1997 Characterization and application of an avian in vitro spermatozoa-egg interaction assay using the inner perivitelline layer from laid chicken eggs. Journal of Reproduction and Fertility 110 205-211.

Rotem R, Paz GF, Homonnai ZT, Kalina M, Lax J, Breitbart H \& Naor Z $1992 \mathrm{Ca}^{2+}$-independent induction of acrosome reaction by protein kinase $\mathrm{C}$ in human sperm. Endocrinology 131 2235-2243.

Topfer-Petersen E, Petrounkina AM \& Ekhlasi-Hundrieser M 2000 Oocyte-sperm interactions. Animal Reproduction Science 60-61 653-662.

Urner F \& Sakkas D 2003 Protein phosphorylation in mammalian spermatozoa. Reproduction 125 17-26.

Waclawek M, Foisner R, Nimpf J \& Schneider WJ 1998 The chicken homologue of zona pellucida protein-3 is synthesized by granulosa cells. Biology of Reproduction 59 1230-1239.

Wishart GJ 1982 Maintenance of ATP concentrations in and of fertilizing ability of fowl and turkey spermatozoa in vitro. Journal of Reproduction and Fertility 66 457-462.

Wishart GJ \& Ross FH 1985 Characterization of a spectrophotometric technique for the estimation of fowl and turkey sperm motility. Gamete Research 11 169-178.

Wishart GJ \& Ashizawa K 1987 Regulation of the motility of fowl spermatozoa by calcium and cAMP. Journal of Reproduction and Fertility 80 607-611.

Received 12 May 2004

First decision 19 July 2004

Revised manuscript received 30 July 2004

Accepted 13 August 2004 